\title{
GIS AND DBMS IMPLEMENTATION FOR THE DEVELOPMENT OF RURAL AREAS OF THE "ONE HUNDRED MASSERIE" OF CRISPIANO
}

\author{
Domenica COSTANTINO ${ }^{I}$, Maria Giuseppa ANGELINI ${ }^{1}$, Michele CLAVERI ${ }^{1}$, \\ Vincenzo Saverio ALFIO ${ }^{I}$
}

DOI: 10.21163/GT_2016.111.04

\begin{abstract}
:
This paper describes the creation of a management and control instrument, with the aim of monitoring, evaluating and increasing all of the information about the rural heritage in the "Cen Masserie" area, located in Crispiano (Taranto). The main goal was to fulfill the European directives, promoted in the "Rural Development Programme" (PSR). The directives aim at the protection and promotion of this heritage and can take place thanks to the financial measures of the Region Apulia. An integrated methodological approach was adopted in order to give a basic structure to any kind of territorial project, be it cognitive, metric or structural. Therefore a Geographic Information System (G.I.S) was created in order to edit, store and manage the information about all the rural structures in the "Cento Masserie" area. On a Microsoft Access database a DBMS (database management system) was created to gain an easier management, storage and review of data. The result represents a useful basis and an operative support, that is able to give information in different ways. It will also be at the authorities and different territorial users disposal, in order to functionally recover this heritage from the architectural and structural point of view and also to protect it, preserve it and use it.
\end{abstract}

Key-words: GIS, Integrated survey, Topographic and Cadastral databases, Data process, Georeferencing

\section{INTRODUCTION}

The project aims to promote rural heritage in the "Cento Masserie" area, located in Crispiano through in-depth knowledge, targeted enhancement and development, giving support to economic and social activities of the territory. The attention has been focused on the case study of the Masseria Lupoli where, after a careful preliminary planning, an integrated survey methodology was conducted, which was useful both to produce metric data for a detailed cataloguing and representation of structural elements present in the site, and to verify and mitigate the risks, which these structures undergo over time in terms of illegal building, as well as to promote their knowing. The whole project has been implemented in the GIS system, by using the national geodetic spatial reference system, as required by the recent legislation on the matter.

Later, a storage system for the information about the rural heritage was realized, creating a DBMS developed in Microsoft Access database, which was connected to the geographic positioning system (GIS), through an OLE DB connection (Object Linking and Embedding Database Provider), devoted to archiving and processing alphanumeric data. This choice of keeping the data in the Access database and update them from time to time within the application GIS, apparently expensive, meets instead the operating cost criteria. Then a connection between the two types of databases has been created, with the main prerogative of keeping the permanent communication between the two different storage systems (Dardanelli

\footnotetext{
${ }^{I}$ Technical University of Bari, 70125 Bari, Italy, domenica.costantino@poliba.it,
} mariagiuseppa.angelini@poliba.it,m.cla0885@gmail.com,vincy870@libero.it 
2015). With this system it is possible to identify priorities for action, and to have information with different interpretations, such as the historical architectural heritage description, the spatial location and exploitation from the point of view of tourism strategy in the territory (Baiocchi 2014).

\section{CARTOGRAPHY AND REFERENCE SYSTEM}

The With the publication of D.P.C.M. on 10 November 2011, by implementing art. 59 of the Digital Administration Code (DAC), Italy adopted the reference system called ETRF2000 (2008.0) and conformed to the European geodetic reference system (ETRF89), in order to support applications that require a higher precision. Considering the common use of GIS, normally oriented to the management of the cartography, the orthoimage or the georeferencing objects with decimeter accuracy, and in order to simplify the procedure, the difference between the ETRF89 and ETRF2000 was not considered, which affects the number of centimeters. The cartographic reference system used for this work is the representation UTM (Universal Transverse Mercator), associated with WGS84 ellipsoid, called ETRS 1989UTM Zone 33N; that was the official geodetic system adopted by Europe concerning the realization ETRF89, at that time (Barbarella, 2014, Mugnier 2005). The map, acquired by the SIT of the Region Apulia and subsequently georeferenced in the reference system in use, is:

- $\quad$ Regional Technical Map (CTR) scale 1: 5.000 in vector format (.shp), concerning the whole territory of study, with the reference system UTM33 - WGS84, made by a flight of aerophotogrammetry during the years 2006/2007 (Timar 2011);

- Color Orthophoto scale 1: 5.000 with a pixel ground resolution of $0.50 \mathrm{~m}$, with UTM33 WGS84 reference system.

\section{STUDY AND CENSUS OF RURAL ARCHITECTURE}

The first phase concerned the creation of a storage structure, in the ArcMap system, for editing, storing and management of geographical information relating to rural goods within the area of interest; the first step to build a GIS is the collection of geographic data and their storage in the geodatabase in the proper format, according to the type of collected data.

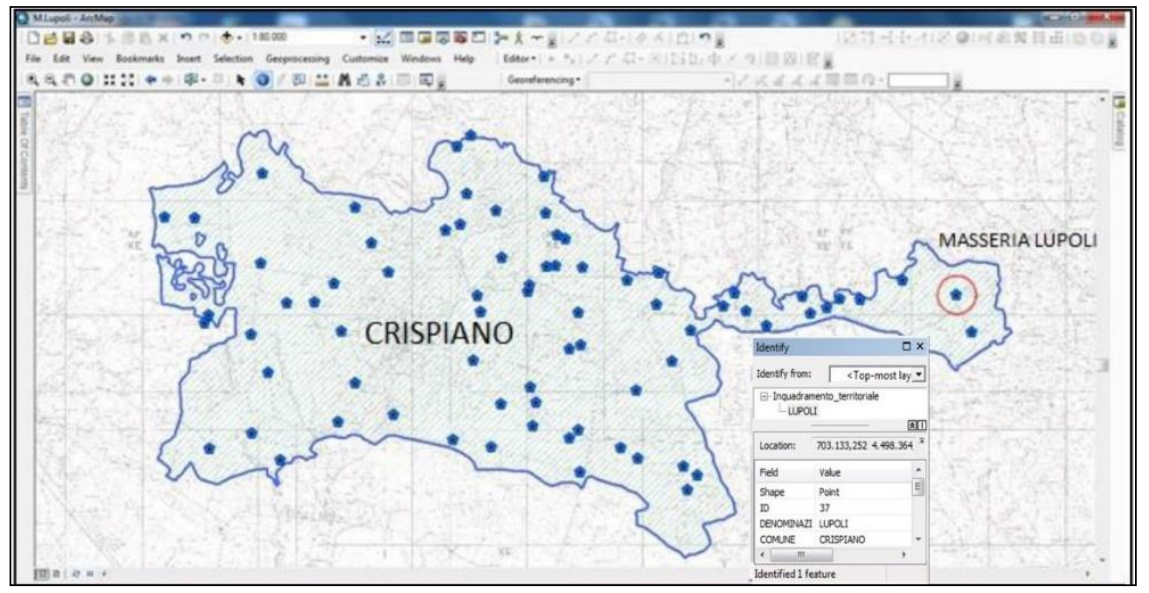

Fig. 1. Land survey and mapping of census 
The aim was to conduct a census of the various farms within the municipal administrative boundary of Crispiano and to check the distribution over the territory, in order to have a general quantitative framework of architectural structures in the zone. 78 rural structures have been identified, then georeferred in the global reference system, using as a basis the I.G.M. cartography scale 1: 25.000 imported into ArcGIS software, through WMS services offered by the National Geoportal and verifying later the exact positioning, the thematic layers such as CTR and orthophotos. Within the attribute table, each specific reference was uniquely identified with a serial number (Fig.1), directly implementing in the Access database a number of other information such as the name, the cartographic and geographic coordinates in the global reference system WGS84/ETRS89 and its administrative location (Tab. 1).

Table 1. The attribute table.

\begin{tabular}{|c|c|c|c|c|c|c|c|c|c|c|}
\hline \multicolumn{11}{|l|}{ Table } \\
\hline 坓・是一 & & 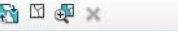 & & & & & & & & \\
\hline \multicolumn{11}{|c|}{ Inquadramento_territoriale } \\
\hline Shape* & ID & DENOMNATION & EST & NORD & DISTRICT & PROVINCE & DISTRUCT COOE & CADNSTRK COOE & LONGITUDE & LATTUDE \\
\hline \begin{tabular}{|l|} 
Point \\
\end{tabular} & 1 & ACCHILLE & 693047,134 & 4496943,6 & CRISPIANO & TARANTO & 73004 & D171 & $17^{\circ} 16^{\prime} 53,763^{\prime \prime} \mathrm{E}$ & $40^{\circ} 36^{\prime} 2,810^{\prime \prime} \mathrm{N}$ \\
\hline Point & 2 & ALEZZA & 687474,998 & \begin{tabular}{|l|l|l|l}
4496062,535 \\
\end{tabular} & CRISPIANO & $\begin{array}{l}\text { TARANTOO } \\
\end{array}$ & 73004 & D171 & $17^{\circ} 12^{\prime} 55,908^{\prime \prime} \mathrm{E}$ & $40^{\circ} 35^{\prime} 38,871^{\prime \prime} \mathrm{N}$ \\
\hline Point & 3 & BELFIORE & 691269,131 & \begin{tabular}{|l|l|}
4495514,847 \\
\end{tabular} & CRISPIANO & TARANTO & 73004 & D171 & $17^{\circ} 15^{\prime \prime} 36,609^{\prime \prime} \mathrm{E}$ & $40^{\circ} 35^{\prime} 17,996^{\prime \prime} \mathrm{N}$ \\
\hline Point & 4 & BELLMONTE & 690007,066 & 4494570,282 & CRISPIANO & TARANTO & 73004 & D171 & $17^{\circ} 14^{\prime} 41,936^{\prime \prime} \mathrm{E}$ & $40^{\circ} 34^{\prime} 48,432^{\prime \prime} \mathrm{N}$ \\
\hline Point & 5 & CACCAVELLA & 687467,06 & 4500650,42 & CRISPIANO & TARANTO & 73004 & D171 & $17^{\circ} 13^{\circ} 0,485^{\prime \prime} \mathrm{E}$ & $40^{\circ} 38^{\prime} 7,560^{\prime \prime} \mathrm{N}$ \\
\hline Point & 6 & CACCIAGUALANI & 684768,305 & 4497332,538 & CRISPIANO & TARANTO & 73004 & D171 & $17^{\circ} 11^{\prime} 2,175^{\circ} \mathrm{E}$ & $40^{\circ} 36^{\prime} 22,222^{\prime \prime} \mathrm{N}$ \\
\hline Point & 7 & CALVELLO & 693317,565 & 4493734,428 & CRISPIANO & TARANTO & 73004 & D171 & $17^{\circ} 17^{1} 1,720^{\prime \prime} \mathrm{E}$ & $40^{\circ} 34^{\prime} 18,586^{\prime \prime} \mathrm{N}$ \\
\hline Point & 8 & CALZEROSSE & 700602,253 & 4498245,751 & CRISPIANO & TARANTO & 73004 & D171 & $17^{\circ} 22^{\circ} 16,453^{\prime \prime} \mathrm{E}$ & $40^{\circ} 36^{\prime} 38,533^{\prime \prime} \mathrm{N}$ \\
\hline Point & 9 & \begin{tabular}{|l|l|} 
CARDELLICCHIO \\
\end{tabular} & 690647,066 & 4498337,294 & CRISPIANO & TARANTO & 73004 & D171 & $17^{\circ} 15^{\prime} 13,238^{\prime \prime} \mathrm{E}$ & $40^{\circ} 36^{\prime} 49,979^{\prime \prime} \mathrm{N}$ \\
\hline Point & 10 & CARMINE & 693324,947 & 4497054,725 & CRISPIANO & TARANTO & 73004 & D171 & $17^{\circ} 17^{\prime} 5,697^{\prime \prime} \mathrm{E}$ & $40^{\circ} 36^{\prime} 6,178^{\prime \prime} \mathrm{N}$ \\
\hline Point & 11 & CARUCCIO & 683666,802 & 4497839,43 & CRISPIANO & TARANTO & 73004 & D171 & $17^{\circ} 10^{\prime} 15,868^{\prime \prime} \mathrm{E}$ & $40^{\circ} 36^{\prime} 39,533^{\prime \prime} \mathrm{N}$ \\
\hline Point & 12 & CASE NUOVE & 693277,322 & 4497904,039 & CRISPIANO & TARANTO & 73004 & D171 & $17^{\circ} 17^{\circ} 4,610^{\circ} \mathrm{E}$ & $40^{\circ} 36^{\prime} 33,741^{\prime \prime} \mathrm{N}$ \\
\hline Point & 13 & $\begin{array}{l}\text { CASELLE DELLE PEZZE } \\
\end{array}$ & 691015,13 & 4494379,782 & CRISPLANO & TARANTO & 73004 & D171 & $17^{\circ} 15^{\prime} 24,574^{\prime \prime} \mathrm{E}$ & $40^{\circ} 34^{\prime} 41,423^{\prime \prime} \mathrm{N}$ \\
\hline Point & 14 & CASELLE MARTUCCI & 692451,82 & 4499110,542 & CRISPLANO & TARANTO & 73004 & D171 & $17^{\circ} 16^{\circ} 30,835^{\prime \prime} \mathrm{E}$ & $40^{\circ} 37^{\prime} 13,532^{\prime \prime N} \mathrm{~N}$ \\
\hline Point & 15 & CASELLONE & 693039,197 & 4494625,845 & CRISPIANO & TARANTO & 73004 & D171 & $17^{\circ} 16^{\circ} 50,872^{\prime \prime} \mathrm{E}$ & $40^{\circ} 34^{\prime} 47,707^{m} \mathrm{~N}$ \\
\hline Point & 16 & CASELLLUZZO & 693277,322 & 4494832,22 & CRISPLANO & TARANTO & 73004 & D171 & $17^{\circ} 17^{\prime} 1,220^{\prime \prime} \mathrm{E}$ & $40^{\circ} 34^{\prime} 54,195^{\prime \prime} \mathrm{N}$ \\
\hline Point & 17 & CIGLIANO & 695709,403 & 4496634,267 & CRISPLANO & TARANTO & 73004 & D171 & $17^{\circ} 18^{\prime} 46,604^{\prime \prime} \mathrm{E}$ & $40^{\circ} 35^{\circ} 50,534^{\prime \prime} \mathrm{N}$ \\
\hline Point & 18 & COMITEO & 690475,379 & 4502539,548 & CRISPIANO & TARANTO & 73004 & D171 & $17^{\circ} 15^{\prime} 10,515^{\prime \prime} \mathrm{E}$ & $40^{2} 39^{\prime} 6,303^{\prime \prime} \mathrm{N}$ \\
\hline Point & 19 & COPPOLA & 703502,092 & 4497399,083 & CRISPIANO & TARANTO & 73004 & D171 & $17^{\circ} 24^{\prime} 18,766^{\prime \prime} \mathrm{E}$ & $40^{\circ} 36^{\prime} 8,547^{\prime \prime} \mathrm{N}$ \\
\hline Point & 20 & DE SLATI & 692682,008 & 4499118,479 & CRISPIANO & TARANTO & 73004 & D171 & $17^{\circ} 16^{\circ} 40,633^{*} \mathrm{E}$ & $40^{\circ} 37^{\prime} 13,596^{\prime \prime} \mathrm{N}$ \\
\hline Point & 21 & DELLE ROSE & 683553,865 & \begin{tabular}{|l|l|}
4497618,289 \\
\end{tabular} & CRISPLANO & TARANTO & 73004 & D171 & $17^{\circ} 10^{\prime} 10,833^{\prime \prime} \mathrm{E}$ & $40^{\circ} 36^{\prime} 32,457^{\prime \prime N}$ \\
\hline Point & 23 & FOGLIANO & 694375,9 & 4494358,846 & CRISPIANO & TARANTO & 73004 & D171 & $17^{\circ} 17^{\prime} 47,389^{\prime \prime} \mathrm{E}$ & $40^{\circ} 34^{\prime} 37,929^{\prime \prime} \mathrm{N}$ \\
\hline Point & 24 & FORNACE & 686411,371 & 4498181,852 & CRISPIANO & TARANTO & 73004 & D171 & $17^{\circ} 12^{\prime} 12,945^{\prime \prime} \mathrm{E}$ & $40^{\circ} 36^{\prime} 48,419^{\prime \prime} \mathrm{N}$ \\
\hline Point & 25 & FRANCESCA & 694778,068 & 4495861,682 & CRISPLANO & TARANTO & 73004 & D171 & $17^{\circ} 18^{\prime} 6,151^{\prime \prime} \mathrm{E}$ & $40^{\circ} 35^{\prime} 26,289^{\prime \prime} \mathrm{N}$ \\
\hline Point & 26 & IMMACOLATELLA & 700057,135 & 4498262,969 & CRISPLANO & TARANTO & 73004 & D171 & $17^{\circ} 21^{\prime} 53,295^{\prime \prime} \mathrm{E}$ & $40^{\circ} 36^{\prime} 39,566^{\prime \prime} \mathrm{N}$ \\
\hline Point & 27 & $\begin{array}{l}\text { INGEGNA DEI PRETI } \\
\end{array}$ & 696005,737 & 44993882,595 & CRISPIANO & TARANTO & 73004 & D171 & $17^{\circ} 18^{\prime} 56,125^{\prime \prime} \mathrm{E}$ & $40^{\circ} 34^{\prime} 21,112^{\prime \prime} \mathrm{N}$ \\
\hline Point & 28 & INGEGNA GRANDE & 696365,571 & 4493649,761 & CRISPIANO & TARANTO & 73004 & D171 & $17^{\circ} 19^{\prime} 11,156^{\prime \prime} \mathrm{E}$ & $40^{\circ} 34^{\prime} 13,260^{\prime \prime} \mathrm{N}$ \\
\hline Point & 29 & JAZZO DELLE FABBRICHE & 691277,658 & 4499341,743 & CRISPIANO & TARANTO & 73004 & D171 & $17^{\circ} 15^{\circ} 41,152^{\prime \prime} \mathrm{E}$ & $40^{\circ} 37^{\prime} 22,006^{\prime \prime} \mathrm{N}$ \\
\hline Point & 31 & LA CHIESA & 694816,243 & 4494078,507 & CRISPLANO & TARANTO & 73004 & D171 & $17^{\circ} 18^{\prime} 5,792^{\prime \prime} \mathrm{E}$ & $40^{\circ} 34^{\circ} 28,471^{\prime \prime} \mathrm{N}$ \\
\hline Point & 32 & LA GROTTA & $\begin{array}{ll}690126,128 \\
\end{array}$ & 4502245,86 & CRISPIANO & TARANTO & 73004 & D171 & $17^{\circ} 14^{\prime} 55,335^{\prime \prime} \mathrm{E}$ & $40^{\circ} 38^{\prime} 57,075^{m} \mathrm{~N}$ \\
\hline Point & 33 & LA SCORCOLA & 696111,57 & 4493258,177 & CRISPIANO & TARANTO & 73004 & D171 & $17^{\circ} 18^{\prime} 59,924^{\prime \prime} \mathrm{E}$ & $40^{\circ} 34^{\prime} 0.787^{\prime \prime} \mathrm{N}$ \\
\hline Point & 34 & L'AMASTUOLA & 683684,04 & 4494335,861 & CRISPIANO & TARANTO & 73004 & D171 & $17^{\circ} 10^{\prime} 12,927^{\prime \prime} \mathrm{E}$ & $40^{\circ} 34^{\prime} 45,974^{\prime \prime} \mathrm{N}$ \\
\hline Point & 35 & LELLA & 692729,633 & 4499920,168 & CRISPIANO & TARANTO & 73004 & D171 & $17^{\circ} 16^{\prime} 43,542^{\prime \prime} \mathrm{E}$ & $40^{\circ} 37^{\prime} 39,536^{\prime \prime N} \mathrm{~N}$ \\
\hline Point & 36 & LE MONACHE & 697637,346 & 4497934,385 & CRISPIANO & TARANTO & 73004 & D171 & $17^{\circ} 20^{\prime} 10,033^{\prime \prime} \mathrm{E}$ & $40^{\circ} 36^{\prime} 31,014^{\prime \prime} \mathrm{N}$ \\
\hline Point & 37 & LUPOLI & 703092,367 & $\begin{array}{l}4498358,629 \\
\end{array}$ & CRISPIANO & TARANTO & 73004 & D171 & $17^{\circ} 24^{\prime} 2,461^{-} \mathrm{E}$ & $40^{\circ} 36^{\prime} 40,002^{-N} \mathrm{~N}$ \\
\hline Point & 38 & MAGGIO & 692928.071 & $\mid$\begin{tabular}{|l|}
$\mid 4499816,98$ \\
\end{tabular} & CRISPIANO & TARANTO & 73004 & D171 & $17^{\circ} 16^{\prime} 51,869^{\prime \prime} \mathrm{E}$ & $40^{\circ} 37^{\circ} 36,025^{\prime \prime} \mathrm{N}$ \\
\hline Point & 39 & MARINOSCI & 686911,434 & 4498658,103 & CRISPIANO & TARANTO & 73004 & D171 & $17^{\circ} 12^{\prime} 34,720^{\prime \prime} \mathrm{E}$ & $40^{\circ} 37^{\prime} 3,447^{\prime \prime} \mathrm{N}$ \\
\hline Point & 40 & MASSERIA NUOVA & 691134,193 & 4500563,107 & CRISPIANO & TARANTO & 73004 & D171 & $17^{\circ} 15^{\prime} 36,386^{\prime \prime} \mathrm{E}$ & $40^{\circ} 38^{\prime} 1,705^{\prime \prime} \mathrm{N}$ \\
\hline Point & 41 & MASSERIOLA & 685514,92 & 4494049,266 & CRISPLANO & TARANTO & 73004 & D171 & $17^{\circ} 11^{\prime} 30,446^{\prime \prime} \mathrm{E}$ & $40^{\circ} 34^{\prime} 35,216^{\prime \prime} \mathrm{N}$ \\
\hline Point & 42 & MEDICHICCHIO & 694545,234 & \begin{tabular}{|l|l|}
4498750,938 \\
\end{tabular} & CRISPIANO & TARANTO & 73004 & D171 & $17^{\circ} 17^{\prime} 59,464^{\prime \prime} \mathrm{E}$ & $40^{\circ} 37^{\circ} 0,114^{\prime \prime} \mathrm{N}$ \\
\hline Point & 43 & MEDICO DI MAGLIE & 692015,257 & 4495959,348 & CRISPIANO & TARANTO & 73004 & D171 & $17^{\circ} 16^{\circ} 8,812^{\prime \prime} \mathrm{E}$ & $40^{\circ} 35^{\circ} 31,779^{\prime \prime} \mathrm{N}$ \\
\hline Point & 44 & MESOLE & 685697,584 & \begin{tabular}{|l|l|}
4498143,178 \\
\end{tabular} & CRISPIANO & TARANTO & 73004 & D171 & $17^{\circ} 11^{\prime} 42,549^{\prime \prime} \mathrm{E}$ & $40^{\circ} 36^{\prime} 47,744^{-1} \mathrm{~N}$ \\
\hline Point & 45 & MESOLECCHIA & 687109,872 & 4497403,976 & CRISPIANO & TARANTO & 73004 & D171 & $17^{\circ} 12^{\prime} 41,818^{\prime \prime} \mathrm{E}$ & $40^{\circ} 36^{\prime} 22,642^{\prime \prime} \mathrm{N}$ \\
\hline Point & 46 & MIOLA & 688475,125 & 4495229,096 & CRISPIANO & TARANTO & 73004 & D171 & $17^{\circ} 13^{\prime} 37,530^{\prime \prime} \mathrm{E}$ & $40^{\circ} 35^{\prime} 11,044^{\prime \prime} \mathrm{N}$ \\
\hline Point & 47 & MITA & 699300,764 & 4497879,322 & CRISPIANO & TARANTO & 73004 & D171 & $17^{\circ} 21^{\prime} 20,697^{\prime \prime} \mathrm{E}$ & $40^{\circ} 36^{\prime} 27,792^{\prime \prime} \mathrm{N}$ \\
\hline Point & 48 & MONGELLI & 682514,051 & 4500396,419 & CRISPIANO & TARANTO & 73004 & D171 & $17^{\circ} 9^{\prime} 29,514^{\prime \prime} \mathrm{E}$ & $40^{\circ} 38^{\prime} 3,321^{\prime \prime} \mathrm{N}$ \\
\hline Point & 49 & MONTE SPECCHIA & 684779,377 & 4494745,122 & CRISPIANO & TARANTO & 73004 & D171 & $17^{\circ} 10^{\prime} 59,916^{\prime \prime} \mathrm{E}$ & $40^{\circ} 34^{\circ} 58,360^{\prime \prime} \mathrm{N}$ \\
\hline Point & 50 & MONTI DEL DUCA & 701702,922 & 4498753,752 & CRISPIANO & TARANTO & 73004 & D171 & $17^{\circ} 23^{\prime} 3,838^{\circ} \mathrm{E}$ & $40^{\circ} 36^{\prime} 54,030^{\prime \prime} \mathrm{N}$ \\
\hline Point & 51 & MORTELLA & 693381,065 & 4499079,022 & CRISPLANO & TARANTO & 73004 & D171 & $17^{\circ} 17^{\prime} 10,320^{\prime \prime} \mathrm{E}$ & $40^{\circ} 37^{\prime} 11,730^{\prime \prime} \mathrm{N}$ \\
\hline Point & 52 & MOSCANINA & 698162,794 & 4497564,591 & CRISPIANO & TARANTO & 73004 & D171 & $17^{\circ} 20^{\prime} 31,956^{\prime \prime} \mathrm{E}$ & $40^{\circ} 36^{\prime} 18,578^{\prime \prime} \mathrm{N}$ \\
\hline Point & 53 & NUOVA & 697028,803 & 4498060,062 & CRISPLANO & TARANTO & 73004 & D171 & $17^{\circ} 19^{\prime} 44,300^{\prime \prime} \mathrm{E}$ & $40^{\circ} 36^{\prime} 35,609^{\prime \prime} \mathrm{N}$ \\
\hline Point & 54 & ORIMINI & 695306,255 & \begin{tabular}{|l|}
4498114,02 \\
\end{tabular} & CRISPLANO & TARANTO & 73004 & D171 & $17^{\circ} 18^{\circ} 31,116^{\prime \prime} \mathrm{E}$ & $40^{\circ} 36^{\prime} 38,829^{\prime \prime} \mathrm{N}$ \\
\hline Point & 55 & PACE & 685061,993 & 4501539,421 & CRISPIANO & TARANTO & 73004 & D171 & $17^{\circ} 11^{\prime} 19,114^{\prime \prime} \mathrm{E}$ & $40^{\circ} 38^{\prime} 38,323^{\prime \prime} \mathrm{N}$ \\
\hline Point & 57 & PICCOLI & 697342,889 & 4498414,322 & CRISPLANO & TARANTO & 73004 & D171 & $17^{\circ} 19^{\prime} 58,054^{\prime \prime} \mathrm{E}$ & $40^{\circ} 36^{\prime} 46,819^{\prime \prime} \mathrm{N}$ \\
\hline Point & 58 & PILANO & 692372,445 & 4501444,171 & CRISPLANO & TARANTO & 73004 & D171 & $17^{\circ} 16^{\prime} 30,027^{\prime \prime} \mathrm{E}$ & $40^{\circ} 38^{\prime} 29,222^{\prime \prime} \mathrm{N}$ \\
\hline Point & 59 & PIZZICA & 685006,431 & 4499181,979 & CRISPIANO & TARANTO & 73004 & D171 & $17^{\circ} 11^{\prime} 14,256^{\prime \prime} \mathrm{E}$ & $40^{\circ} 37^{\prime} 21,968^{\prime \prime} \mathrm{N}$ \\
\hline Point & 60 & PORCILE DI CIGLLANO & 696195,502 & 4497438,29 & CRISPIANO & TARANTO & 73004 & D171 & $17^{\circ} 19^{\prime} 8,170^{\prime \prime} \mathrm{E}$ & $40^{\circ} 36^{\prime} 16,174^{\prime \prime} \mathrm{N}$ \\
\hline Point & 61 & POZZO DEL TERMMTE & 687887,749 & \begin{tabular}{|l|l|}
4499713,793 \\
\end{tabular} & CRISPIANO & TARANTO & 73004 & D171 & $17^{\circ} 13^{\prime} 17,375^{\prime \prime} \mathrm{E}$ & $40^{\circ} 37^{\prime} 36,862^{\prime \prime} \mathrm{N}$ \\
\hline $\begin{array}{l}\text { Point } \\
\end{array}$ & 62 & RUGGERI & 699718,456 & 4498021,945 & CRISPIANO & TARANTO & 73004 & D171 & $17^{\circ} 21^{\prime} 38,619^{\prime \prime} \mathrm{E}$ & $40^{\circ} 36^{\prime} 32,051^{\prime \prime} \mathrm{N}$ \\
\hline Point & 63 & RUSSOLITE & 692428,008 & 4500491,669 & CRISPIANO & TARANTO & 73004 & D171 & $17^{\circ} 16^{\circ} 31,342^{\prime \prime} \mathrm{E}$ & $40^{\circ} 37^{\prime} 58,309^{\prime \prime} \mathrm{N}$ \\
\hline Point & 64 & SAN DOMENICO DI BASSO & 699084,789 & 4498322,5 & CRISPIANO & TARANTO & 73004 & D171 & $17^{\circ} 21^{\prime} 12,018^{\prime \prime} \mathrm{E}$ & $40^{\circ} 36^{\prime} 42,340^{\prime \prime} \mathrm{N}$ \\
\hline Point & 65 & SAN FRANCESCO & 690739,671 & 4497927,189 & CRISPIANO & TARANTO & 73004 & D171 & $17^{\circ} 15^{\prime} 16,729^{\prime \prime} \mathrm{E}$ & $40^{\circ} 36^{\prime} 36,612^{\prime \prime} \mathrm{N}$ \\
\hline Point & 66 & SAN PIETRO & 690538,879 & 4496641,974 & CRISPIANO & TARANTO & 73004 & D171 & $17^{\circ} 15^{\prime} 6,792^{\prime \prime} \mathrm{E}$ & $40^{\circ} 35^{\prime} 55,129^{\prime \prime} \mathrm{N}$ \\
\hline Point & 67 & SAN SIMONE & 691949,711 & 4498447,729 & CRISPIANO & TARANTO & 73004 & D171 & $17^{\circ} 16^{\prime} 8,754^{\prime \prime} \mathrm{E}$ & $40^{\circ} 36^{\prime} 52,473^{\prime \prime} \mathrm{N}$ \\
\hline Point & 68 & SAN SIMONE - MOTOLESE & 691993,367 & \begin{tabular}{|l|l|}
4498614,417 \\
\end{tabular} & CRISPIANO & TARANTO & 73004 & D171 & $17^{\circ} 16^{\circ} 10,793^{\prime \prime} \mathrm{E}$ & $40^{\circ} 36^{\prime} 57,838^{\prime \prime N ~ N ~}$ \\
\hline Point & 69 & SCORACE & 689816,565 & 4500047,168 & CRISPIANO & TARANTO & 73004 & D171 & $17^{\circ} 14^{\prime} 39,776^{\prime \prime} \mathrm{E}$ & $40^{\circ} 37^{\circ} 46,079^{-1} \mathrm{~N}$ \\
\hline Point & 70 & SERRE D'ANTUONO & 688346,733 & 4498953,656 & CRISPLANO & TARANTO & 73004 & D171 & $17^{\circ} 13^{\prime} 36,079^{\prime \prime} \mathrm{E}$ & $40^{\circ} 37^{\prime} 11,852^{\prime \prime} \mathrm{N}$ \\
\hline Point & 71 & $\begin{array}{l}\text { TAGLIENTE } \\
\end{array}$ & 692174,007 & \begin{tabular}{l|l|}
4495554,534 \\
\end{tabular} & CRISPLANO & TARANTO & 73004 & D171 & $17^{\circ} 16^{\prime} 15,117^{\prime \prime} \mathrm{E}$ & $40^{\circ} 35^{\prime} 18,527^{\prime \prime} \mathrm{N}$ \\
\hline Point & 72 & TAGLIENTUDDO & 692078,757 & 4494943,346 & CRISPIANO & TARANTO & 73004 & D171 & $17^{\circ} 16^{\prime} 10,398^{\prime \prime} \mathrm{E}$ & $40^{\circ} 34^{\prime} 58,801^{\prime \prime} \mathrm{N}$ \\
\hline Point & 73 & TORRE GENOVIVA & 687033,632 & 4495044,102 & CRISPIANO & TARANTO & 73004 & D171 & $17^{\circ} 12^{\prime} 36,056^{\prime \prime} \mathrm{E}$ & $40^{\circ} 35^{\prime} 6,226^{\prime \prime} \mathrm{N}$ \\
\hline Point & 74 & TRIGLIO & 685212,806 & 4496324,473 & CRISPIANO & TARANTO & 73004 & D171 & $17^{\circ} 11^{\prime} 20,009^{\prime \prime} \mathrm{E}$ & $40^{\circ} 35^{\circ} 49,195^{\prime \prime} \mathrm{N}$ \\
\hline Point & 75 & TUTTULMO & 695370,736 & 4498930,855 & CRISPIANO & TARANTO & 73004 & D171 & $17^{\circ} 18^{\prime} 34,770^{\prime \prime} \mathrm{E}$ & $40^{\circ} 37^{\prime} 5,244^{\prime \prime} \mathrm{N}$ \\
\hline Point & 76 & VALENTE & 690205,503 & 4500197,981 & CRISPIANO & TARANTO & 73004 & D171 & $17^{\circ} 14^{\prime} 56,484^{\circ} \mathrm{E}$ & $40^{2} 37^{7} 50,644^{\prime \prime} \mathrm{N}$ \\
\hline Point & 77 & VALENTENTUDDO & 690372,191 & 4501007,608 & CRISPIANO & TARANTO & 73004 & D171 & $17^{\circ} 15^{\circ} 4,456^{\prime \prime} \mathrm{E}$ & $40^{\circ} 38^{\prime} 16,743^{\prime \prime} \mathrm{N}$ \\
\hline
\end{tabular}




\section{THE LAND SURVEY: THE CASE OF MASSERIA LUPOLI}

Masseria Lupoli has been used as the rural structure prototype because of its richness in history and its wide space of relevance. Through the use of the Leica Smart Station, a traditional integrated survey for location plan and details with GNSS technology was conducted. Thanks to the features of the Smart Station, the celerimetric survey was performed with the Total Station TS11, by collimating all points of detail of the structure and at the same time, with the help of the GS-12 Leica receiver, it was possible to determine the planimetric and altitude conformation of the entire site. Thanks to the proximity of the permanent station TARA, belonging to the national network GNSS ItalPoS , and materialized at the Center "Magna Grecia" of Politecnico di Bari - Taranto, the kinematic differential GNSS survey was conducted, with the post data- processing, thus achieving considerable advantages in terms of precision and time control (Fig.2),.
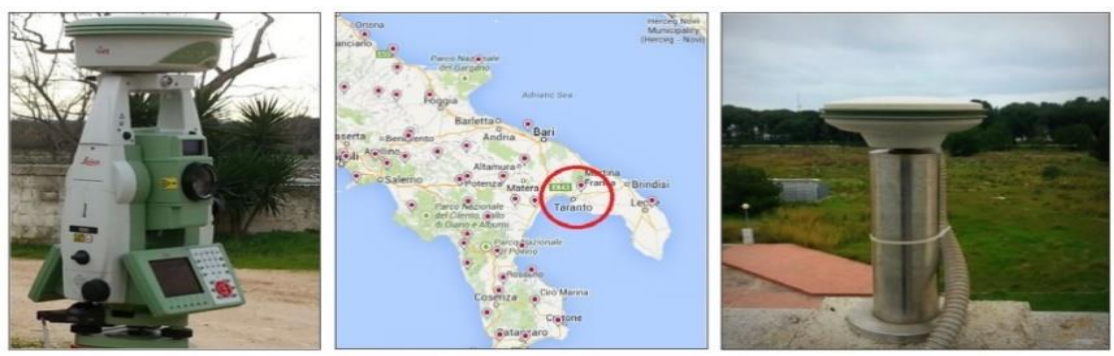

Fig.2. Topogtraphical instruments and permanent station TARA

This was followed by the planimetric graphical representation and the data from the GNSS survey, supplemented with the topographic ones, led to the definition of a DTM (Digital Terrain Model).

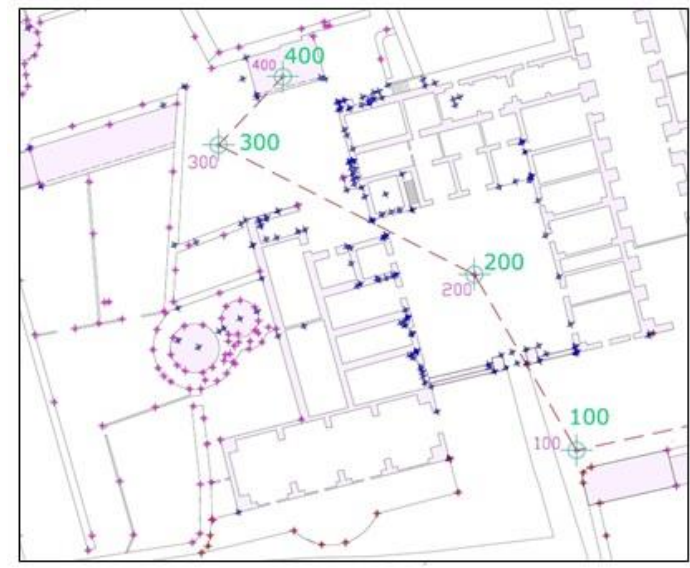

Fig.3. Celerimetric survey

As a result of the detailed celerimetric survey (Fig.3), the plano-altrimetric conformation and the volume of structures inside the farm have been defined, allowing the development and the representation of a simplified three-dimensional model of the complex (Fig.4). 


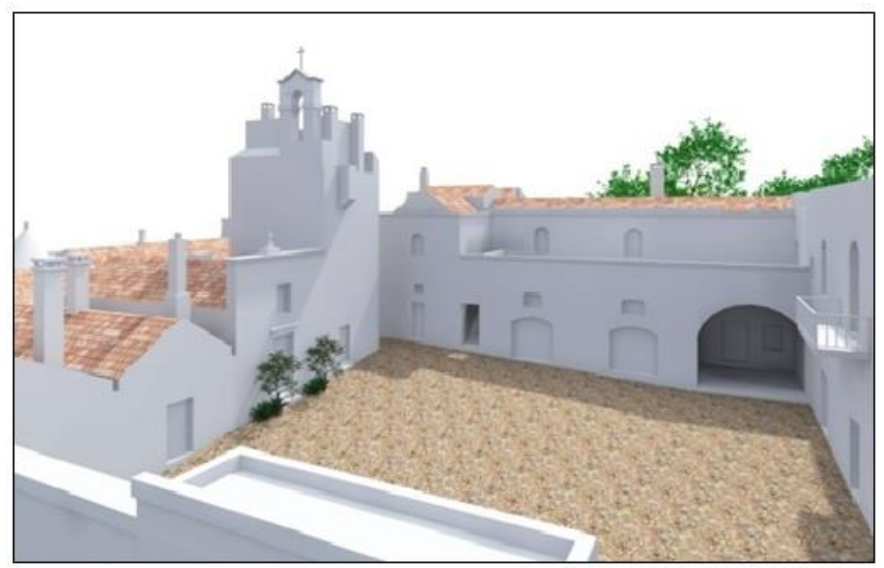

Fig. 4. Restitution of the three-dimensional model simplified

\section{TOPOGRAPHIC AND CADASTRAL DATABASES}

Another goal was to integrate in the topographic database the information concerning the Land Registry database. The acquisition and the geo-reference of cadastral maps, in addition to the other basic maps with different nominal scales, present in the cadastral database of a GIS, allow one to optimally manage the knowledge of rural territories and contribute to solving numerous situations which are not identifiable in the actual maps, such as CTR (Regional Technical Map).

Among the possible and positive reasons for its acquisition, are the management of landscape protection of the Authority, perimeter delimitation according to the "Galassini" Decrees and the perimeters dictated for State concessions. In these cases, the attempt to superimpose analytically incompatible map systems can produce indecision, the uncertainty of a sure answer and often accidental errors or contestable results. A geometrical integration between the two map systems is not feasible, neither for the different ways of measuring and reporting the information, nor for the different systems of reference, unless rigid georeferencing processes are conducted.

\section{DATA PROCESSING}

The cadastral map represents the whole national territory and for its depicted thematic mapping, it is the fundamental instrument for the management of a territory, irrespective of the financial purposes for which it was created. Its characteristics include origins in hundreds of different reference systems, different Datum and map projection than the official national projection, all of which make interaction complex. It is known that the system of map representation, mainly used by the cadaster, is the Cassini-Soldner projection, that is the transverse of equirectangular projection; in this category within the limit Xmax $=70 \mathrm{~km}$, the modulus of surface deformation does not exceed 1.00005 and furthermore, along the central meridian it is both equivalent and conformal. These considerations suggested then to realize the process of integrating the cadaster database, by using the original cadastral maps in raster format, which are not updated but represent the "most precise" available matric basis nowadays (Baiocchi 2013). 
The peculiarity of cadastral maps is how the grid is represented within them, in addition to normal external wire fences (distance of crossroads $400 \mathrm{~m}$, on a scale of 1:4.000); in the process of geo-referencing this pattern is needed to arrange homogeneously the control points $(\mathrm{GCP}=$ ground control point) and to avoid concentrating them in limited areas (such as near borders). In this manner it is possible to make the process of geo-referencing more precise and also to prevent the so-called "flag in the wind" phenomenon (Baiocchi 2010, Baiocchi 2013). The first step was to obtain the original cadastral map of the area of study from the relevant office of Agenzia del Territorio (Real Estate and Land Registry Agency), via a proper application to the Protocol office. This original map was on a scale of 1:4.000, in raster format (.tif) with a resolution of $300 \mathrm{dpi}$.

By using all points of intersection belonging to the parametric grid of the map and through the Cartlab software as GCP (35), the cartographic coordinates in the Gauss-Boaga Rome40 (Surace 1998) projection system have been acquired and later exported into a data table in CSV format (Comma-Separated Values). Through a combining translation and rotation plane motion with variations in the isotropic scale (as indicated in the Directive of the Real Estate and Land Registry Agency in 27/05/2008), the work proceeded with the geo reference of the map thanks to the component ArcMap: the process was possible by means of a polynomial transformation of I type, in line with the concept of cadastral map. The phase of using the shapefile as geo-referenced base for the above-cited Roma40 coordinates was followed by the final conversion of the cadastral coordinates in the European Reference system UTM33 - ETRS89 (D’Anastasio 2010, Maseroli 2002, Maseroli 2002).
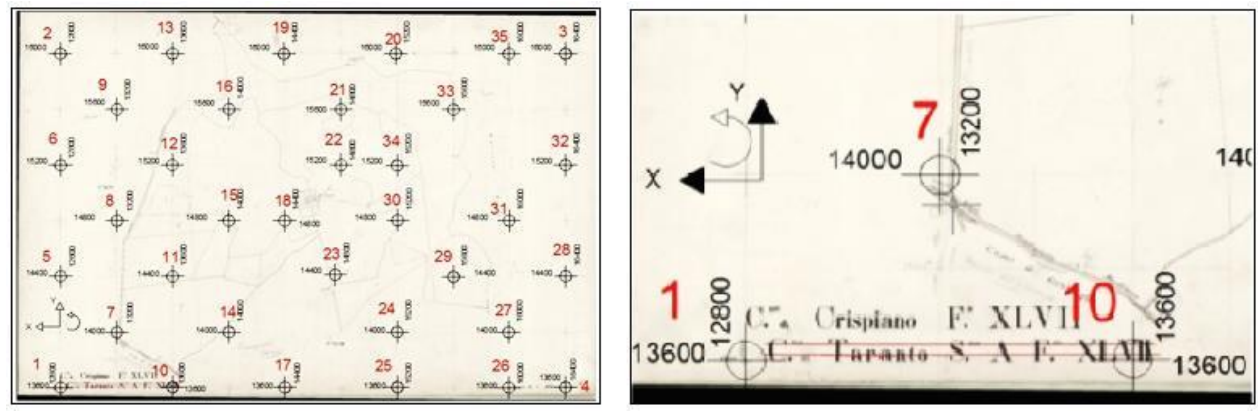

Fig.5. Georeferencing of the plant original sheet (OI)

The superimposition against the technical maps already present in the database has been satisfactory since the beginning, as the accuracy in the transformation into RMS occurred within the range of $60 \mathrm{~cm}$, which is both entirely consistent and below the graphic approximation on the map itself. Anyway, a low value of RMS is not a sign of accuracy in the transformation: normally the accuracy is accepted when the RMSE is smaller than the dimension of a pixel; the pixel measures $34 \mathrm{~cm}$ when it comes from the scan of the original map, on a scale of 1:4.000 with 300 dpi resolution. The following phase consisted in two steps: firstly, the creation of a feature class of the land-use polygons through the identification of the cadastral dividends, which interpret the real delimitation of each parcel and secondly in the storing of information in to an attributes table, such as the identification cadastral code, the extension and the type of cultivation in the soil (Fig. 5). 


\section{IMPLEMENTATION OF RELATIONAL DATABASE RDBMS}

In order to store all information concerning the rural goods within the territory of "Cento Masserie", it has been suitable to implement the relational database DBMS on Microsoft Access (Lee 2013, Kantabutra 2010, Gao 2008)). This database is able to collect many information about each rural good such as technical information, data about location and the related state of preservation, about the dimensioning of the present structures; it gives also the possibility to examine and update any kind of documents, such as cadastral and cartographic maps. After identifying and defining the type of information to be inserted in the database, it was time to create and project the database itself, by means of tables made up of many fields which are connected to each other by primary and secondly relations. The relational database has been created to be easily used through the display of simplified masks. It has been envisaged a first section, which returns a general information about the specific characteristics of the territory, by providing a general list of existing farms as discovery tool for the territory of interest.

The second section, which is made up of two following buttons, describes each rural building and analyses the different aspects, representing a simplified desk study, able to return the complete situation of the studied structure; this last aspect will be useful for future users. The database is essentially structured into 2 modules: the first one enables the storing of information about the specific elements of the structure, its owner, the position, the distance from the built-up area, from train stations or airport, the state of preservation, the availability of the users, the morphologic classification of the rural structures according to the guidelines in the Piano Paesaggistico Territoriale Regionale (Regional Landscape Territorial Plan), drafted by the Region Apulia, and also the possibility to consult cartographic and cadastral documents (Zlatanova 2006). Following the guidelines, it has been possible to classify the different structures according to their settlement morphotypology and to the various territorial fields in the Ionian-Taranto area. The second module is mainly structured to collect and store the survey data, with the related planimetric and three-dimensional graphic representations (Tet-Khuan 2006). Therefore, for any information about the discovery, management or usage of data, this database is made up of interchange files (metadata), which belong to a specific identification code of the farm, within the area of "Cento Masserie di Crispiano" (Fig. 6).

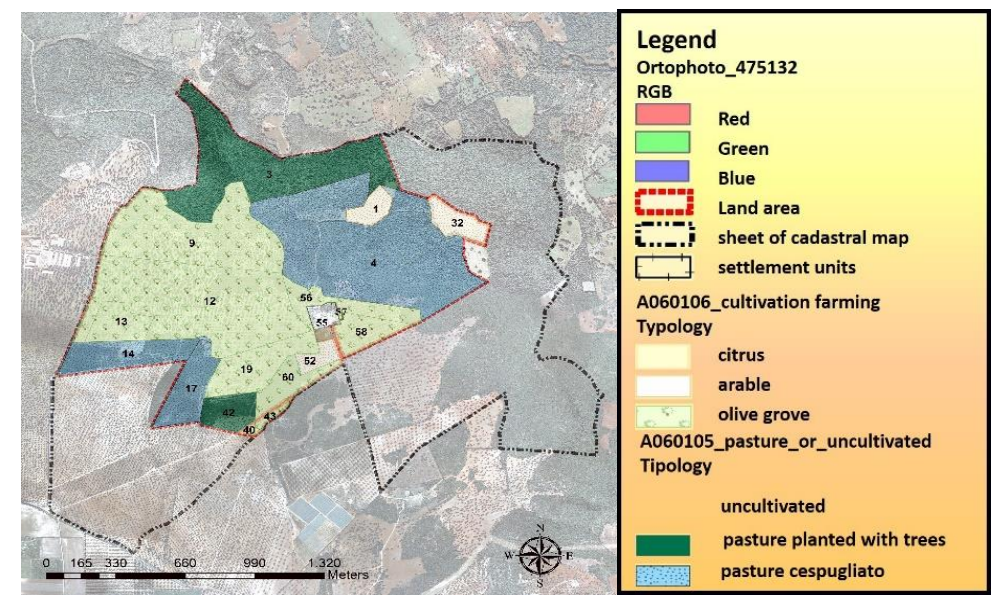

Fig. 5. Identification of cadastral parcels Sheet 47 - City of Crispiano (TA) 


\section{CONCLUSIONS AND FUTURE DEVELOPMENTS}

At the light of the creation of an archive containing different kinds of information, among which the geographical ones, this work represents a real database, which can be share with the different institutions and authorities of the territory and will enable the optimization and the simplification of all administrative and management actions regarding the rural goods, in particular about the farms around the city of Crispiano (Fig. 6a, 6b). Furthermore, the advantages for the institutions are evident: for instance, the City Council could have available the up-dated maps in the official cartographic system, since all data about the territory of their interest could be useful for the map update.

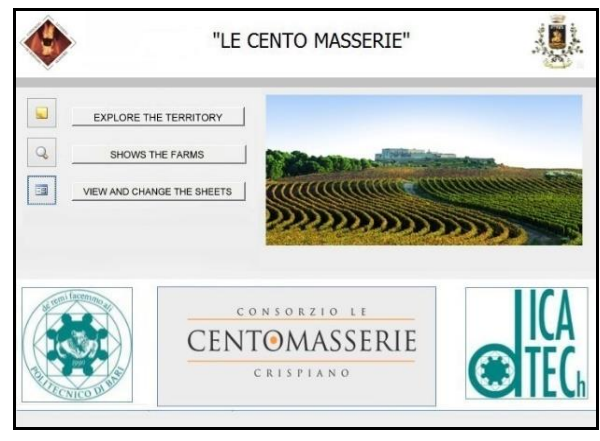

Fig. 6a. Microsoft Access database graphical interface

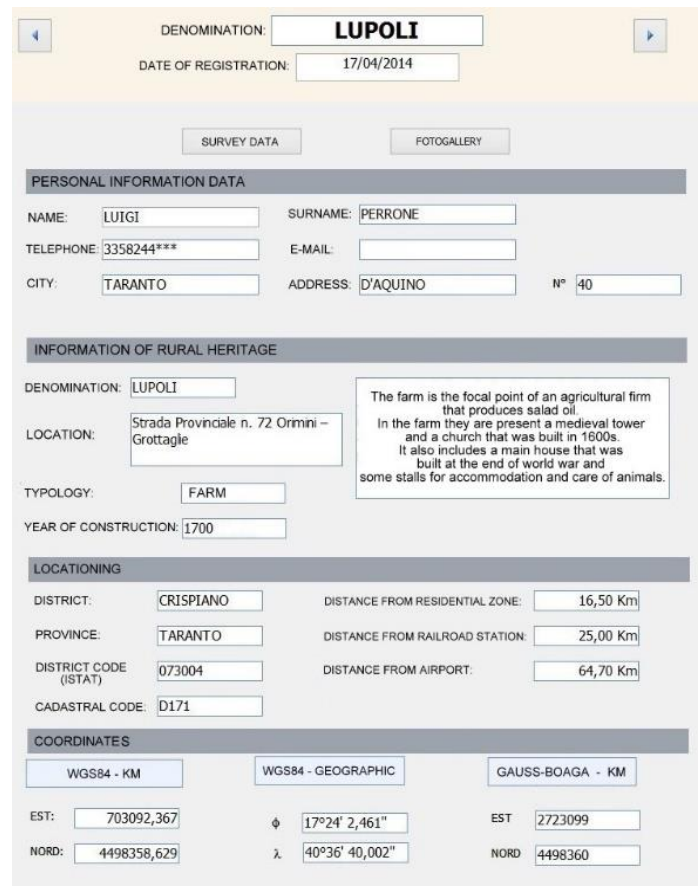

Fig. 6b. Microsoft Access database graphical interface 
After a proper codification in a territorial computer system in WebGIS mode (Yang 2008), the next goal will be to integrate and share these information, which will be consulted and easily traceable on the screen, thus creating a new dynamic kind of cartography, customizable in terms of representation, extremely innovative and different from the raster or numeric traditional cartography and representing an operative support, useful for the promotion of the rural territory (Costantino 2010, Costantino 2008).

It is clear that following analysis will contribute to updating and enriching the actual framework; this project represents obviously the first step toward the real action of promotion of this territory, by means of survey technologies and systems like G.I.S for the organization and management and the planning of the research work, in the field of the preservation of the existing rural built heritage (Crăciunescu 2008).

\section{REFERENCES}

Baiocchi, V., Lelo, K. (2010), Accuracy of 1908 high to medium scale cartography of Rome and its surroundings and related georeferencing problems , Acta Geodaetica et Geophysica Hungarica, 45 (1), pp. 97-104.

Baiocchi, V., Lelo, K., Milone, M.V., Mormile, M (2013), Accuracy of different georeferencing strategies on historical maps of Rome, Geographia Technica, (1), pp. 10-16.

Baiocchi, V., Lelo, K., Milone, M.V., Mormile, M, Tanga, E. (2013), Knowing the past for managing the present: A comparison between historical cartography and satellite images for the study of Rome's city centre, Geographia Technica, (1), pp. 17-27.

Lee, K.-Y., Kim, J. J., Kang, J.-J., Kim, J.-L., Choi, G.-S., Lima, C.-G. (2013), Spatio-temporal lite DBMS for u-GIS, International Journal of Software Engineering and its Applications, 7 (3), pp. $1-12$.

Kantabutra, V., "Jack” Owens, J. B., Ames, D. P., Burns, C.N. (2010), Using the newly-created ile dbms to better represent temporal and historical gis data, Transactions in GIS, 14 (SUPPL. 1), pp. 39-58.

Yang, J. (2008), Computing job accessibility with integrated GIS and DBMS, Proceedings of the 7th International Conference of Chinese Transportation Professionals Congress 2007: Plan, Build, and Manage Transportation Infrastructures in China, pp. 58-66.

D’Anastasio, E., D’Ambrosio, C., Cecere, G., Selvaggi, G., Avallone, A. (2010), La rete GPS permanente della Regione Puglia, Rapporti Tecnici.

Gao, Y.a , Zhou, W.b (2008), Advances and challenges of GIS and DBMS applications in karst Environmental Geology, 54 (5), pp. 901-904.

Tet-Khuan, C., Abdul-Rahmana, A., Zlatanov, S. (2007), 3D spatial operations in geo DBMS environment for 3D GIS, Lecture Notes in Computer Science (including subseries Lecture Notes in Artificial Intelligence and Lecture Notes in Bioinformatics), 4705 LNCS (PART 1), pp. 151-163. Cited 5 times.

Zlatanova, S.a , Stoter, J.b (2006), The role of DBMS in the new generation GIS architecture Frontiers of Geographic Information Technology, pp. 155-180.

Costantino D, M. G. Angelini (2010). Realization of a cartographic GIS for the filing and Management of the archeological excavations in the Nelson's Island. In: Digital Heritage Third International Conference, EuroMed 2010, Lemessos, Cyprus, November 8-13, 2010. Proceedings. vol. 6436/2010, p. 513-527, BERLIN: Springer, ISBN: 978-3-642-16872-7, doi: 0.1007/978-3-642-16873-4_42

Costantino D, M. G. Angelini, G. Caprino (2008). Planning of a metric historical and documental archive for the realization of a city's cultural portal. In: The 14th International Conference on Virtual Systems and Multimedia. Cyprus - Limassol, 20-25 ottobre 2008, vol. Project papers, p. 877-882, BUDAPEST: archaeolingua, ISBN: 978-963-9911-00-00 
Maseroli R. (2002), Passaggio fra sistemi di riferimento geodetici: la nuova procedura adottata dall'IGM - Bollettino di Geodesia e Scienze Affini, anno LXI - n. 1, 2002

Maseroli R. $\left(2002^{1}\right)$, La trasformazione tra sistemi di riferimento utilizzati in Italia - Bollettino di Geodesia e Scienze Affini, anno LXI - n. 4, 2002

Surace L. (1998), La georeferenziazione delle informazioni territoriali. Bollettino di Geodesia e Scienze Affini, vol. LVII, no. 2, pp. 181-234.

Barbarella, M. (2014) Digital technology and geodetic infrastructures in Italian cartography. Citta e Storia, $\mathrm{N}^{\circ} 1 / 2014$ gennaio-giugno, Anno IX

Baiocchi, V., Lelo, K., Polettini, A., \& Pomi, R. (2014) Land suitability for waste disposal in metropolitan areas. Waste Management and Research, 32 (8), 707-716

Crăciunescu V., Constantinescu Şt., Ovejeanu I., (2008), Developing an open Romanian geoportal using free and open source software. Geographia Technica, 3(1), pp. 15-20.

Dardanelli, G., Paliaga, S., Allegra, M., Carella, M., \& Giammarresi, V. (2015) Geomatic applications to urban park in Palermo. Geographia Technica, 1/2015, 28-43

DMA, Defense Mapping Agency, (1990), Datums, Ellipsoids, Grids and Grid Reference Systems. DMA Technical Manual 8358.1. Fairfax, Virginia, USA.

Mugnier C.J., (2005), Grids \& Datums - Italian Republic. Photogrammetric Engineering \& Remote Sensing. 71, pp. 899-890.

Timar G., Baiocchi V., Lelo K. (2011) Geotetic Datums of the Italian cadastral systems, Geographia Technica, Issue no. 1/2011, pp. 82-90 